\title{
Penerapan Bimbingan Kelompok dengan Teknik Modeling Simbolis untuk Meningkatkan Motivasi Belajar Siswa
}

\author{
Sitti Nurkia ${ }^{1}$, Sulkifly ${ }^{2}$ \\ Mandrasah Aliyah Negeri 1 Enrekang, Indonesia ${ }^{1}$ \\ Jurusan Manajemen Pendidikan, Universitas Negeri Gorontalo, Indonesia ${ }^{2}$ \\ st.nurkia@yahoo.com
}

Diterima: September 2020

Disetujui: Oktober 2020

Dipublikasi: November 2020

\begin{abstract}
Abstrak
Penelitian ini menelaah tentang cara menangani motivasi belajar siswa melalui teknik modeling simbolis dalam kegiatan bimbingan kelompok pada peserta didik kelas X IPS 3 SMA Laboratorium Percontohan UPI. Tujuan penelitian ini adalah untuk mendeskripsikan prosedur penerapan bimbingan kelompok dengan teknik modeling simbolis yang dapat meningkatkan motivasi belajar siswa di Kelas X IPS 3 SMA Laboratorium Percontohan UPI tahun pelajaran 2018/2019 dan untuk menganalisis dampak penerapan bimbingan kelompok dengan teknik modeling simbolis terhadap peningkatan motivasi belajar siswa di Kelas X IPS3 SMA Laboratorium Percontohan UPI tahun pelajaran 2018/2019. Penelitian ini menggunakan pendekatan kualitatif. Analisis data menggunakan deskriptif komparatif membandingkan kondisi sebelum pemberian tindakan dan setelah pemberian tindakan. Hasil penelitian menunjukkan bahwa: adanya peningkatan yang berarti. Peningkatan tersebut dapat dilihat pada hasil observasi dan pengisian inventori. Hal ini terbukti dari keberhasilan peserta didik dalam mengikuti kegiatan layanan bimbingan kelompok siklus pertama ke siklus ketiga motivasi belajar meningkat. Kesimpulan penelitian ini adalah penerapan bimbingan kelompok dengan teknik modeling simbolis pada peserta didik kelas X IPS 3 SMA Laboratorium Percontohan UPI dapat meningkatkan motivasi belajar siswa.
\end{abstract}

Kata Kunci: Motivasi; Belajar; Bimbingan Kelompok, Modeling Simbolis

\begin{abstract}
This study examines how to deal with student learning motivation through symbolic modeling techniques in group guidance activities for students of class X IPS 3 at UPI Pilot Laboratory High School. The purpose of this study is to describe the procedure for applying group guidance with symbolic modeling techniques that can improve student learning motivation in IPS X Class 3 UPI Pilot School High School 2018/2019 academic year and to analyze the impact of applying group guidance with symbolic modeling techniques to increase learning motivation students in Class X IPS3 High School Pilot Laboratory UPI academic year 2018/2019. This study used a qualitative approach. Data collection using questionnaire and observation instruments. Data analysis using descriptive comparative comparing conditions before giving action and after giving action. The results showed that: there was a significant increase. This increase can be seen in the results of observation and inventory filling. This is evident from the success of students in participating in the first cycle group guidance service activities to the third cycle of learning motivation increases. The conclusion of this study is the application of group guidance with symbolic modeling techniques to students of class X IPS 3 High School Pilot Laboratory UPI can increase student learning motivation.
\end{abstract}

Keywords: Learning Motivation, Group Guidance, Symbolic Modeling

This is an open access article distributed under CC BY-SA 4.0 


\section{PENDAHULUAN}

Upaya untuk mencerdaskan bangsa pada dasarnya dapat dihasilkan melalui kegiatan belajar di sekolah, namun pada kenyataanya seringkali terdapat kesenjangan antara target pembelajaran dengan hasil pembelajaran yang dicapai oleh para peserta didik, sehingga prestasi akademik yang diinginkan belum dicapai secara optimal. Tentu saja hal ini tidak hanya bertumpu pada aspek pengajar dan metode pembelajaran saja, namun juga peran dari dalam diri peserta didik itu sendiri mengambil bagian dalam peningkatan hasil belajar sehingga target pembelajaran bisa dicapai. Dalam dunia pendidikan, motivasi untuk belajar merupakan salah satu hal yang penting. Tanpa motivasi, seseorang tentu tidak akan mendapatkan proses belajar yang baik. Motivasi merupakan langkah awal terjadinya pembelajaran yang baik. Pembelajaran dikatakan baik jika tujuan awal, umum dan khusus tercapai. Peserta didik yang mempunyai need to know kebutuhan akan keingintahuan yang tinggi, mempunyai karakteristik yang berbeda dalam hal psikologis mereka. Motivasi belajar tentu berkaitan dengan psikologis peserta didik. Motivasi belajar setiap orang, satu dan lainnya, bisa jadi tidak sama. Biasanya, hal itu bergantung dari apa yang diinginkan orang yang bersangkutan.

Motivasi belajar merupakan faktor psikis yang bersifat non intelektual, peranannya yang khas dalam hal penumbuhan gairah, merasa senang dan semangat untuk belajar. Adanya motivasi dalam diri peserta didik akan membangkitkan semangat belajar bagi peserta didik itu sendiri. Artinya bahwa bila seorang peserta didik mempunyai motivasi sukses yang lebih kuat, maka ia akan mencari jalan keluar dari kesulitan yang dihadapinya. Akan tetapi bila motivasi suksesnya itu lemah, maka ia cenderung untuk mencari jalan pintas dan bahkan menempuh jalan yang sulit sebagai bentuk pelarian dari masalah yang dihadapinya itu. Pada dasarnya guru dapat secara kreatif mencoba dan mengembangkan model pembelajaran tersendiri yang khas, sesuai dengan kondisi nyata ditempat kerja masing-masing, sehingga pada gilirannya akan muncul model-model pembelajaran versi guru yang bersangkutan, yang tentunya semakin memperkaya khazanah model pembelajaran yang telah ada. Pembelajaran merupakan suatu konsep dari kegiatan belajar mengajar yang harus direncanakan dan diaktualisasikan, serta diarahkan pada pencapaian tujuan atau penguasaan sejumlah kompetensi yang indikatornya sebagai gambaran hasil belajar. Oleh sebab itu kegiatan pembelajaran akan bermuara pada dua kegiatan pokok. Pertama, tindakan perubahan tingkah laku melalui kegiatan belajar. Kedua, tindakan penyampaian ilmu pengetahuan melalui kegiatan mengajar. Dapat di tarik kesimpulan bahwa prinsip dari mengajar adalah mempermudah dan memberikan motivasi kegiatan belajar. Menumbuhkan motivasi peserta didik dalam belajar sangatlah penting agar peserta didik dapat memenuhi tugasnya yaitu belajar.

Berdasarkan hasil pengamatan selama melakukan Praktik Pengalaman Lapangan (PPL) terdapat beberapa peserta didik yang sering acuh tak acuh dalam mengikuti pelajaran, sering tidak memperhatikan disaat guru menjelasakan, tidak bersemangat dalam mengikuti pelajaran, sulit berkonsentrasi saat proses pembelajaran, tidak aktif dalam belajar dan peserta didik tidak bisa menjawab pertanyaan yang diberikan oleh guru. Jika hal tersebut tidak diatasi dengan baik maka dapat menimbulkan dampak negatif misalnya prestasi belajarnya rendah serta tidak mempunyai minat dalam belajar. Mengetahui 
permasalahan tersebut, perlu kiranya ada solusi yang tepat untuk membuka wawasan dalam meningkatkan motivasi belajar peserta didik. Salah satu cara yang dianggap dapat meningkatkan motivasi belajar peserta didik adalah bimbingan kelompok. Menurut Gazda sebagaimana dikutip oleh (Prayitno, 2004), bahwa bimbingan kelompok di sekolah merupakan kegiatan informasi kepada sekelompok peserta didik untuk membantu mereka menyusun rencana keputusan yang tepat. Bimbingan kelompok memiliki nilai yang khas, karena layanan ini memanfaatkan dinamika dalam kelompok selama proses layanan dilaksanakan. Sedangkan menurut (Prayitno, 1995) bimbingan kelompok berarti memanfaatkan dinamika untuk mencapai tujuan-tujuan bimbingan dan konseling. Bimbingan kelompok lebih merupakan suatu upaya bimbingan kepada individu-individu melalui kelompok. Alasan kenapa menggunakan layanan bimbingan kelompok adalah karena tidak dapat dipungkiri, pengaruh teman sebaya kepada seorang anak begitu tinggi. Bahkan, sering kali lebih tinggi dibandingkan dengan pengaruh kedua orang tuanya atau guru-gurunya (Mifzal, 2012). Adapun teknik yang digunakan dalam bimbingan kelompok ini adalah teknik modeling simbolis.

Teknik modeling simbolis merupakan bagian dari pendekatan behavioristik. Teknik Modeling Simbolis, dimana yang menjadi modelnya adalah video atau film, sehingga peserta didik terdorong untuk belajar. Modeling adalah suatu strategi dalam konseling yang menggunakan proses belajar melalui pengamatan terhadap model dan perubahan perilaku yang terjadi karena peniruan. Dengan menggunakan teknik modeling simbolis kaitannya dengan belajar yakni peserta didik dapat meniru perilaku yang diharapkan dengan mencontoh atau mengamati model yang sudah disediakan, dengan begitu peserta didik akan memiliki kesadaran dan tumbuh motivasi dalam belajar.

\section{METODE}

Pendekatan yang digunakan atau dipilih dalam pelaksanaan penelitian ini adalah pendekatan kualitatif. Pendekatan ini dipilih untuk mendeskripsikan motivasi belajar siswa dalam pelaksanaan tindakan bimbingan kelompok. Jenis penelititan yang digunakan adalah penelitian tindakan kelas yang bersifat deskriptif. Untuk memberikan pemecahan yang tepat terhadap permasalahan penelitian yang dikemukakan maka ada beberapa fokus penelitian yang akan diselidiki adalah motivasi belajar dan bimbingan kelompok dengan teknik modeling simbolis Penelitian ini menggunakan prosedur penelitian tindakan kelas (action research), yaitu rencana penelitian berdaur ulang (siklus) yang terdiri dari: perencanaan, pelaksanaan, pengamatan (observasi), dan refleksi. Subjek penelitian adalah siswa binaan sekolah mitra, yaitu siswa kelas X IPS 3 SMA Laboratorium Percontohan UPI tahun pelajaran 2018/2019.

Prosedur pengumpulan data digunakan dengan teknik non-tes yaitu berupa angket dan observasi. Angket adalah suatu metode untuk mengumpulkan data yang berupa suatu pernyataan (statement) tentang sifat, keadaan, kegiatan tertentu dan sejenisnya. Dari daftar peryataan tersebut subjek/ individu yang hendak kita kumpulkan datanya diminta untuk memilih mana-mana pernyataan yang cocok dengan dirinya diisi tanda cek atau tandatanda lain yang ditetapkan. Angket berupa daftar pernyataan yang harus dipilih oleh subjek/responden sesuai dengan keadaan dirinya. Untuk menghitung data dari responden 
dilakukan pemberian skor bagi masing-masing kontinum secara berurut. Pedoman observasi disusun dengan mengacu pada penerapan bimbingan kelompok dengan teknik Modeling Simbolis untuk meningkatkan motivasi belajarpeserta didik. Pedoman observasi ini disusun untuk mengamati atau mencatat reaksi-reaksi dan partisipasi peserta didik selama mengikuti proses kegiatan pemberian layanan atau tindakan selama pelaksanaan layanan bimbingan kelompok. Pedoman observasi yang digunakan adalah lembar pengamatan kemampuan peneliti dalam pemberian layanan dan lembar pengamatan aktivitas peserta didik dalam kegiatan.

Pengumpulan data dalam penelitian ini dilakukan mulai pada pra penelitian (Pretest) sampai dengan akhir tindakan (Post-test) dengan tujuan untuk mengetahui masalah yang dihadapi Guru BK dan siswa dalam proses pemberian layanan. Dalam hal ini dilakukan observasi dan angket sebagai langkah awal untuk memperoleh data yang akurat. Selanjutnya pada proses penelitian tetap menggunakan teknik yang ada ditambahkan catatan lapangan yang memuat hal-hal penting yang terjadi selama proses bimbingan berlangsung yang dapat digunakan untuk melengkapi data yang tidak terekam dalam lembar observasi.

Setelah semua data yang diperlukan diperoleh, langkah berikutnya adalah menganalisa data tersebut sehingga dapat di interpretasikan. Dalam menganalisis data tersebut peneliti menggunakan perbandingan nilai pretest $(\mathrm{O} 1)$ dengan nilai posttest $(\mathrm{O} 2)$ yang dikemukakan oleh (A. Muri Yusuf, 2005) dengan langkah-langkah sebagai berikut:

$$
\begin{array}{ll}
P=\frac{f}{N} & x 100 \\
\mathrm{P} & : \text { Persentase } \\
\mathrm{f} & : \text { Frekuensi } \\
\mathrm{N} & : \text { Jumlah sampel }
\end{array}
$$

Dalam penasiran data, selanjutnya merubah data tesebut dari persentase kedalam bentuk kriteia-kriteria penafsiran. Kemudian batas skor tinggi sekali dikurangi interval dan itulah yang dijadikan batas skor tinggi $(\mathrm{T})$, begitu seterusnya sampai hasil pengurangan nantinya adalah nilai terendah $(\mathrm{R})$, dan rendah sekali (RS).

\section{HASIL TEMUAN}

Prosedur dan hasil penelitian tindakan bimbingan dan konseling terdiri dari 5 bagian, yaitu Pre-test, siklus I, siklus II, siklus III dan Post-test. Data hasil penelitian ini

\begin{tabular}{|c|c|c|c|c|}
\hline Siklus & $\begin{array}{c}\text { Hari/ } \\
\text { Tanggal }\end{array}$ & Materi & Teknik & Metode \\
\hline Pre-test & $\begin{array}{c}\text { Senin, 24/9/ } \\
2018\end{array}$ & $\begin{array}{c}\text { Pembagian Angket } \\
\text { Motivasi Belajar }\end{array}$ & - & - \\
\hline Siklus I & $\begin{array}{c}\text { Senin, } \\
15 / 10 / 2018\end{array}$ & $\begin{array}{l}\text { Belajar untuk meraih } \\
\text { cita-cita }\end{array}$ & Modeling Simbolis & $\begin{array}{c}\text { Common Reading } \\
\text { dan Pemberian } \\
\text { Tugas }\end{array}$ \\
\hline Siklus II & Selasa, & 59 & Modeling Simbolis & Common Reading \\
\hline
\end{tabular}
kemudian dijadikan bahan untuk dijabarkan dalam pembahasan. Adapun waktu pelaksanaan penelitian dijabarkan sebagai berikut:

\section{Tabel 1. Jadwal Pelaksanaan Penelitian}




\begin{tabular}{ccccc} 
& $30 / 10 / 2018$ & Inspirasiku & & dan menulis \\
$\begin{array}{c}\text { Siklus } \\
\text { III }\end{array}$ & $\begin{array}{c}\text { Selasa,13/11 } \\
/ 2018\end{array}$ & Motivatorku & Modeling Simbolis & Common Reading \\
\hline Post-test & Rabu, & $\begin{array}{c}\text { Pembagian Angket } \\
\text { Motivasi Belajar }\end{array}$ & - & - \\
& $14 / 11 / 2018$ & Motivi Bund & \\
\hline
\end{tabular}

\section{Data Hasil Angket Motivasi Belajar Pada Tahap Pre-test}

Peneliti mengadministrasikan angket Pre-test pada 26 orang peserta didik kelas X IPS 3 di SMA Laboratorium Percontohan UPI

\section{Siklus I}

Tabel 2. Hasil Observasi Siswa Dalam Bimbingan Kelompok Siklus I

\begin{tabular}{lcc}
\hline \multicolumn{1}{c}{ Presentase } & Kriteria & Siklus 1 \\
\hline $\mathbf{8 0} \% \mathbf{- 1 0 0 \%}$ & Sangat Tinggi & 1 orang \\
$\mathbf{6 0 - 7 9 \%}$ & Tinggi & 2 orang \\
$\mathbf{4 0 - 5 9 \%}$ & Sedang & 3 orang \\
$\mathbf{2 0 \% - 3 9 \%}$ & Rendah & - \\
$\mathbf{0 - 1 9 \%}$ & Sangat rendah & - \\
\hline \multicolumn{2}{c}{ Jumlah } & 6 orang \\
\hline
\end{tabular}

Berdasarkan tabel diatas diketahui bahwa tingkat keaktifan siswa dalam bimbingan kelompok untuk meningkatkan motivasi belajarsiswa yang berjumlah 6 orang pada siklus 1 berada pada kategori Sangat tinggi sebanyak 1 orang, kategori tinggi 2 orang, kategori sedang sebanyak 3 orang. Sedangkan tidak ada siswa yag berada pada kategori rendah dan sangat rendah.

\section{Hasil Pengamatan Terhadap Tindakan Peneliti}

\section{Observer 1}

Berdasarkan hasil observasi, kegiatan bimbingan kelompok yang dilaksanakan peneliti pada bagian RPL pada umumnya sesuai dengan panduan operasional penyelenggaraan bimbingan dan konseling akan tetapi pada tahap kerja bagian generalisasi perlu penjabaran secara spesifik. Tahap pelaksanaan tindakan pada tahap awal bagian menjelaskan langkah-langkah, dan melakukan konsolidasi peneliti masih kurang sehingga perlu di eksplor lebih lanjut. Pada tahap transisi bagian storming dan norming belum maksimal di dalam memfasilitasi anak-anak untuk mengikuti tahap selanjutnya.

Observer 2

Berdasarkan hasil observasi, kegiatan bimbingan kelompok yang dilaksanakan peneliti pada bagian RPL pada umumnya sesuai dengan panduan operasional penyelenggaraan bimbingan dan konseling akan tetapi perlu ditingkatkan kembali karena belum mencapai nilai maksimal 4. Tahap pelaksanaan tindakan pada tahap transisi bagian storming dan norming belum maksimal di dalam memfasilitasi anak-anak untuk mengikuti tahap selanjutnya. Tahap kerja bagian generalisasi perlu penjabaran secara spesifik,serta tahap akhir bagian tindak lanjut perlu dikembangkan agar peserta didik dapat 
mengaplikasikan ke dalam kehidupan sehari-hari serta antusias untuk ikut dalam pertemuan selanjutnya.

\section{Siklus II}

\section{Hasil Pengamatan Terhadap Siswa}

Berdasarkan pengamatan terhadap peserta didik saat mengikuti kegiatan bimbingan kelompok untuk meningkatkan motivasi belajar siswa maka diperoleh hasilnya sebagai berikut :

Tabel 3. Hasil Observasi Siswa Dalam Bimbingan Kelompok Siklus II

\begin{tabular}{lcc}
\hline \multicolumn{1}{c}{ Presentase } & Kriteria & Siklus 1 \\
\hline $\mathbf{8 0} \% \mathbf{- 1 0 0 \%}$ & Sangat Tinggi & 3 orang \\
$\mathbf{6 0 - 7 9 \%}$ & Tinggi & 3 orang \\
$\mathbf{4 0 - 5 9 \%}$ & Sedang & - \\
$\mathbf{2 0 \% - 3 9 \%}$ & Rendah & - \\
$\mathbf{0 - 1 9 \%}$ & Sangat rendah & - \\
\hline & & $\mathbf{6}$ orang \\
\hline
\end{tabular}

Berdasarkan tabel diatas diketahui bahwa tingkat keaktifan siswa dalam bimbingan kelompok untuk meningkatkan motivasi belajarsiswa yang berjumlah 6 orang pada siklus II berada pada kategori Sangat tinggi sebanyak 3 orang, kategori tinggi 3 orang, Sedangkan tidak ada siswa yag berada pada kategori sedang, rendah dan sangat rendah.

\section{Hasil Pengamatan Terhadap Tindakan Peneliti}

Pada siklus II pengamatan juga dilakukan bersamaan dengan tindakan, dengan menggunakan instrument observasi yang sama dengan siklus I.

Observer 1

Berdasarkan hasil observasi, kegiatan bimbingan kelompok yang dilaksanakan peneliti pada bagian RPL pada umumnya sesuai dengan panduan operasional penyelenggaraan bimbingan dan konseling akan tetapi perlu ditingkatkan kembali untuk mencapai nilai maksimal. Tahap pelaksanaan tindakan pada tahap awal, tahap transisi, dan tahap kerja perlu adanya usaha untuk mencapai nilai yang maksimal agar kegiatan berjalan dengan lancar sesuai yang diharapkan.

Observer 2

Berdasarkan hasil observasi, kegiatan bimbingan kelompok yang dilaksanakan peneliti pada bagian RPL pada umumnya sesuai dengan panduan operasional penyelenggaraan bimbingan dan konseling akan tetapi perlu ditingkatkan kembali untuk mencapai nilai maksimal. Tahap pelaksanaan tindakan pada tahap kerja perlu penjabaran secara spesifik.

\section{Siklus III}

Kegiatan yang dilaksanakan pada layanan bimbingan kelompok penerapan teknik Modeling Simbolis untuk meningkatkan motivasi belajar siswa di kelas X IPS 3 di SMA Laboratorium Percontohan UPI pada tindakan Siklus III meliputi perencanaan, pelaksanaan, observasi, 


\section{Pengamatan Terhadap Siswa}

Berdasarkan pengamatan terhadap peserta didik saat mengikuti kegiatan bimbingan kelompok untuk meningkatkan motivasi belajar siswamaka diperoleh hasilnya sebagai berikut:

Tabel 4. Hasil Observasi Siswa Dalam Bimbingan Kelompok Siklus III

\begin{tabular}{|c|c|c|}
\hline Presentase & Kriteria & Siklus 1 \\
\hline $80 \%-100 \%$ & Sangat Tinggi & 5 orang \\
\hline $60-79 \%$ & Tinggi & 1 orang \\
\hline $40-59 \%$ & Sedang & - \\
\hline $20 \%-39 \%$ & Rendah & - \\
\hline 0-19\% & Sangat rendah & - \\
\hline \multicolumn{2}{|c|}{ Jumlah } & 6 orang \\
\hline
\end{tabular}

Berdasarkan tabel diatas diketahui bahwa tingkat keaktifan siswa dalam bimbingan kelompok untuk meningkatkan motivasi belajarsiswa yang berjumlah 6 orang pada siklus III berada pada kategori Sangat tinggi sebanyak 5 orang, kategori tinggi 1 orang, Sedangkan tidak ada siswa yag berada pada kategori sedang, rendah dan sangat rendah.

\section{Hasil Pengamatan Terhadap Tindakan Peneliti}

\section{Observer 1}

Berdasarkan hasil observasi, kegiatan bimbingan kelompok yang dilaksanakan peneliti pada bagian RPL pada umumnya sesuai dengan panduan operasional penyelenggaraan bimbingan dan konseling akan tetapi perlu ditingkatkan kembali untuk mencapai nilai maksimal. Tahap pelaksanaan tindakan pada tahap awal bagian melakukan konsolidasi perlu mengarahkan peserta didik dengan baik agar tugas dan tanggung jawab dapat dipahami dengan baik. Tahap kerja bagian analisis dan generalisasi perlu adanya usaha untuk mencapai nilai yang maksimal agar kegiatan berjalan dengan lancar sesuai yang diharapkan dan penjabarannya secara maksimal agar peserta didik paham dengan kegiatan yang dilaksanakan.

Observer 2

Berdasarkan hasil observasi, kegiatan bimbingan kelompok yang dilaksanakan peneliti pada bagian RPL pada umumnya sesuai dengan panduan operasional penyelenggaraan bimbingan dan konseling akan tetapi perlu ditingkatkan kembali untuk mencapai nilai maksimal. Tahap pelaksanaan tindakan pada tahap kerja perlu penjabaran secara spesifik. Tahap akhir bagian tindak lanjut perlu di optimalkan agar peserta didik dapat mengaplikasikan kegiatan yang telah dilakukan dalam kehidupan sehari-hari.

\section{Analisis Data Setelah Tindakan}

Setelah selesai siklus III peserta didik dibagikan angket (Post-Test). Kemudian membandingkan dengan hasil angket yang telah diberikan sebelumnya pada pelaksanaan pra tindakan (Pre-Test). Berdasarkan hasil analisis angket diketahui bahwa terjadi perubahan setelah pelaksanaan tindakan. Dimana pada saat pre-test siswa berada pada kualifikasi rendah sekali (3,8\%), rendah (3,8\%), dan cukup tinggi (19,2\%), setelah 
diberikan tindakan (post-test) terjadi perubahan dimana tidak ada lagi kualifikasi rendah sekali, rendah, dan cukup tinggi. Tetapi meningkat menjadi 2 orang $(33,3 \%)$ untuk kualifikasi tinggi dan 4 orang $(66,7 \%)$ untuk kualifikasi sangat tinggi.

\section{PEMBAHASAN}

Perilaku yang penting bagi manusia adalah belajar dan bekerja, belajar menimbulkan perubahan mental pada diri manusia. Bekerja menghasilkan sesuatu yang bermanfaat bagi diri perilaku dan orang lain. Motivasi belajar dan motivasi bekerja merupakan kemajuan penggerak masyarakat. Motivasi belajar sangat penting bagi peserta didik, seperti yang dikemukakan oleh (Mulyasa, 2002) Bahwa pentingnya motivasi disebabkan karena sebagai berikut:

a. Menyadarkan kedudukan pada awal belajar, proses, dan hasil akhir.

b. Menginformasikan tentang kekuatan usaha belajar yang dibandingkan dengan teman sebaya.

c. Mengarahkan kegiatan belajarnya.

d. Membesarkan semangat belajarnya.

e. Menyadarkan tentang adanya perjalanan belajar dan kemungkinan bekerja yang berkesinambungan.

Berdasarkan hasil penelitian pada pelaksanaan siklus I dimana perubahan yang terjadi belum signifikan dan perlu ditingkatkan lagi keaktifan siswa dalam memberikan tanggapan karena terdapat siswa yang masih terbilang pasif dalam memberikan tanggapan. Peneliti lebih giat dalam meningkatkan kemampuan dalam pelaksanaan kegiatan yang masih banyak kekuarangan agar materi bimbingan dapat dipahami dan diterima oleh peserta didik yang diberikan layanan sehingga tujuan yang ingin dicapai bisa terlaksana dengan baik.

Pada pelaksanaan siklus II terdapat perubahan yang terjadi cukup signifikan dan perlu ditingkatkan lagi keaktifan siswa dalam memberikan tanggapan agar motivasi belajar siswa tercapai secara maksimal. Peneliti terus belajar untuk meningkatkan kemampuan diri di dalam mengolah kegiatan menjadi lebih terarah dan lebih baik dari sebelumnya. Kemudian hasil penelitian pada pelaksanaan siklus III terjadi perubahan yang dianggap signifikan dan dengan menggunakan teknik modeling simbolis dapat meningkatkan motivasi belajar siswa. Peneliti mengalami kemajuan di dalam pemberian layanan bimbingan kelompok walaupun belum mendapatkan nilai maksimal secara keseluruhan, tetapi terus belajar dalam meningkatkan kemampuan diri untuk menjadi lebih baik lagi kedepannya.

Berdasarkan hasil observasi, peneliti menarik kesimpulan bahwa pelaksanaan siklus III terjadi perubahan yang dianggap signifikan dan dengan menggunakan teknik modeling simbolis dapat meningkatkan motivasi belajar siswa. Peneliti mengalami kemajuan di dalam pemberian layanan bimbingan kelompok walaupun belum mendapatkan nilai maksimal secara keseluruhan, tetapi terus belajar dalam meningkatkan kemampuan diri untuk menjadi lebih baik lagi kedepannya. 
Menurut Mc. Donald (Sardiman A.M, 2010 ) motivasi adalah perubahan energi dalam diri sesorang yang ditandai dengan munculnya "feeling" dan didahului dengan tanggapan terhadap adanya tujuan. Menurut Eysenck dkk (Slameto A.M, 2003) motivasi dirumuskan sebagai suatu proses yang menentukan tigkatan kegiatan, intensitas, konsitensi, serta arah umum dari tingkah laku manusia, merupakan konsep yang rumit dan berkaitan dengan konsep-konsep lain seperti minat, konsep diri, sikap, dan sebagainya. Menurut Mortensen \& Schmuller (dalam Nandang Rusmana, 2009) mengemukakan bahwa Guidance may be defined as the part of total educational program that help provide the personal opportunities and specialized staff servise by which each individual can develop to the fullest of his abilities and capacities in term of the democratic idea. Layanan bimbingan kelompok merupakan salah satu strategi layanan BK berupa suatu bentuk proses yang memungkinkan peserta didik secara bersama-sama memperoleh berbagai bahan dari narasumber yang nantinya bermanfaat untuk kehidupan sehari-hari, baik bagi pelajar, anggota keluarga, dan masyarakat.

Bimbingan bertujuan untuk perbaikan kehidupan orang yang dibimbing, yaitu untuk (a). mengatur kehidupan sendiri, (b). mengembangkan atau memperluas pandangan, (c). menetapkan pilihan, (d). mengambil keputusan, (e). memikul beban kehidupan, (f). menyesuaikan diri, (g). mengembangkan kemampuan (Nandang Rusmana, 2009: 12). Pada layanan bimbingan kelompok para peserta didik dapat memperoleh pemahaman dan pengarahan diri yang diperlukan untuk menyesuaikan diri dan mengembangkan nilai-nilai yang terdapat pada diri individu.

Berdasarkan pelaksanaan tindakan yang dilakukan oleh peneliti dengan penerapan bimbingan kelompok dengan teknik modeling simbolis untuk meningkatkan motivasi belajar siswa di Kelas X IPS 3 SMA Laboratorium Percontohan UPI tahun pelajaran 2018/2019 memprlihatkan hasil yang signifikan, ditandai dengan adanya peningkatan motivasi belajar siswa. Dari hasil penelitian di atas, tampak bahwa penerapan teknik modeling simbolis dalam kegiatan bimbingan kelompok dapat meningkatkan motivasi belajar siswa.

\section{SIMPULAN}

Berdasarkan hasil penelitian dan pembahasan, maka dapat diambil kesimpulan prosedur penerapan bimbingan kelompok teknik modeling simbolis dapat meningkatkan motivasi belajar siswa kelas X IPS 3 di SMA Laboratorium Percontohan UPI tahun pelajaran 2018/2019, yaitu dengan melalui tahapan Atensi yaitu tahap untuk mulai memberi perhatian pada model. Namun dengan catatan bahwa perilaku yang dimodeling haruslah spesifik dan sesuai dengan tujuan pelaksanaan tindakan bimbingan kelompok. Reproduksimerupakan tahap dimana peserta didik menunjukkan tingkah laku seperti tingkah laku model yang dapat ditiru jika dikaitkan kedalam kehidupan masing-masing anggota kelompok. Penerapan bimbingan kelompok dengan teknik modeling simbolis terbukti berdampak positif dalam menangani masalah motivasi belajarsiswa kelas X IPS 3 di SMA Laboratorium Percontohan UPI tahun pelajaran 2018/2019, dengan melihat hasil observasi dan membandingkan hasil angket pada pra tindakan (pretest) dan setelah 
tindakan (posttest). Hal ini dapat dicapai karena siswa secara terus menerus diberikan bimbingan secara intensif.

\section{DAFTAR PUSTAKA}

Arikunto, Suharsimi. (2006). Prosedur Penelitian Suatu Pendekatan Praktik. Jakarta: PT RINEKA CIPTA.

Djamarah, Syaiful Bahri. (2011). Psikologi Belajar. Jakarta: Rineka Cipta.

Gunarsa, S. D. (1989). Psikologi Perkembangan Anak dan Remaja. Jakarta: BPK. Gunung Mulia.

Hamalik, Oemar. (2014). Psikologi Belajar \& Mengajar. Bandung: Sinar Baru Algensindo.

Hurlock, E.B. (1991). Psikolgi Perkembangan Suatu Pendekatan Sepanjang Rentang Kehidupan (Terjemahan oleh Istiwidayanti dan Soedjarwo). Jakarta: Penerbit Erlangga.

Lilis Ratna Purnamasari. (2012). “Teknik-teknik Konseling”. Fakultas Negeri Semarang.

Nandang Rusmana. 2009. Bimbingan Dan Konseling Kelompok Di Sekolah. Bandung: Rizqi Press.

Nursalim, M. (2005). Strategi Konseling. Surabaya: UNESA.

Oyon. (2011). Teknik Modeling. (Online). Http://Kangmasoyon.blogspot.com/ (diakses 09 Mei 2018).

Prayitno. (1995). Layanan Bimbingan dan Konseling kelompok (Dasar dan Profil),Jakarta: Ghalia Indonesia.

Prayitno. (2004). Layanan Bimbingan Kelompok dan Konseling Kelompok. Padang: Jurusan Bimbingan dan Konseling Universitas Negeri Padang.

Purwanto, Ngalim. (2013). Psikologi Pendidikan. Bandung: PT. Remaja Rosdakarya Offset.

Sardiman, A.M. (2010). Interaksi dan Motivasi Belajar Mengajar. Jakarta: Rajawali Pers.

Santrok, J. W. (2003). Adolescence (Perkembangan Remaja). Terjemahan. Jakarta: Penerbit Erlangga.

Siregar, Eveline dan Hartini Nara. (2014). Teori Belajar dan Pembelajaran.Bogor: Ghalia Indonesia.

Surya, M. (2003). Psikologi Konseling. Pustaka Bani Quraisy: Bandung.

Umar, A dan Kaco, N. (2008). Penelitian Tindakan Kelas. Makassar: Badan Penerbit UNM

Yusuf, A.M. (2005). Metodologi Penelitian Dasar-Dasar Penelitian Ilmiah. Padang: UNP Press. 